\title{
Managing Institutional Complexity through Strategy and Structure: The Experience of Sri Lanka's Peak Business Interest Associations
}

\author{
Kevin You and Gustavo Guzman \\ Griffith Business School, Griffith University, Australia \\ Word count: 8,796
}

\begin{abstract}
This study seeks to better understand the way, in which business interest associations in a developing country address issues associated the plurality of logics and interest among their members. The dilemma that business associations face, when it comes to representing the various interests of their constituents under a single banner, is adequately documented. But there is a gap in empirical literature on the way that associations successfully address this dilemma from the top down, especially in a developing country like Sri Lanka.

We present a case study of the four most prominent peak national business associations in Sri Lanka - and their attempts at reconciling the diverse voices and interests of their members. We find that insights from contemporary institutional logics literature are particularly helpful in explaining the strategic and structural means, by which Sri Lankan business associations address the issue of presenting a united front for the very diverse groups of firms and industries that make up their membership. Specifically, our observation shows that Sri Lanka's peak business associations respond to the diverse, and at times competing, interests of their members in ways that are consistent with Kraatz and Block's characterisation of organisational responses to institutional complexity, namely through: elimination/marginalisation, mediation, compartmentalisation and detachment.
\end{abstract}

Key Words: Business associations, interest groups, institutional complexity, institutional pluralism, Sri Lanka

Corresponding Author: Kevin You, Griffith University, Nathan Campus, Nathan Qld 4111; Email: kevin.you@griffithuni.edu.au 


\section{Introduction}

Business interest associations are important actors in the political and economic landscapes of a country. ${ }^{1}$ Their influence on public policy has been shown to be significant at critical junctures in a nation's political and economic trajectory. ${ }^{2}$ Prominent associations frequently act as partners and trusted advisors to government bodies ${ }^{3}$ - and they regularly have easy access to key policy makers. ${ }^{4}$ State functions, such as the issuing of certificates of origin and registering of bids for government projects, are often outsourced by governments and entrusted to major peak national associations. ${ }^{5}$ Business associations are complex, diverse, interesting and worthwhile subject for organisational research (Lawton, Rajwani \& Minto, 2018; Windmuller \& Gladstone, 1984).

However, studies into these important institutional actors are few and far between. ${ }^{6}$ Political science literature abounds with references to the activities, behaviours and socio-economic roles of individual enterprises, entrepreneurs, business leaders and indeed capitalists as a class in society. ${ }^{7}$ But the subject of formal and collective associations of capital is largely under-researched. This is particularly true when it comes to associations that operate in developing markets, which is peculiar because there is much academic interest in the rise and operations of trade unions across the developing world. ${ }^{8}$

The precious few academic studies on business interest representatives in developing economies tend to focus on their relationships with facets of their external environment such as the government, ${ }^{9}$ markets, ${ }^{10}$ members of the political establishment, ${ }^{11}$ and firms in the private sector. ${ }^{12}$ The present study focuses inwards - namely on the way that business interest associations in developing countries

\footnotetext{
${ }^{1} \mathrm{CCD}, 2011$

2 e.g. Thornthwaite \& Sheldon, 2012

3 e.g. ILO, 2010

${ }^{4}$ Nguyen, 2014a; 2014b; Schmitter \& Streeck, 1999; Kowal, 2018; Lucas, 1997

5 e.g. Hicks, 2012; Moore \& Hamalai, 1993

${ }^{6}$ Barry, Michelotti \& Nyland, 2006; Barry \& Wilkinson, 2011a; 2011b; Schmitter \& Streeck, 1999

${ }^{7}$ per Schmitter \& Streeck, 1999

8 e.g. Das, 2008; Freeman, 2009; Gallin, 2001; Sirait, 2014

${ }^{9}$ Doner \& Schneider, 2000; Goldsmith, 2002; Kowal, 2018; Önis \& Türem, 2001

${ }^{10}$ Doner \& Schneider, 2000

${ }^{11}$ Nguyen, 2014a; 2014b

12 Goldsmith, 2002
} 
address competing logics that invariably reside within them - something that the aforementioned texts have largely neglected.

The dilemma that business associations face, when it comes to representing the various interests of their members under a single banner, is adequately documented - especially in developed, industrialised economies. ${ }^{13}$ But there is a gap in empirical literature on the way that associations successfully address this dilemma, especially in developing countries. Schmitter and Streeck $^{14}$ suggest that organisational structures play a critical part in dealing with discrepancies in the views and interests of business association members. Olson ${ }^{15}$, on the other hand, points towards the political power and will of the most influential actors within these associations as key determinants of association strategic and policy positioning. ${ }^{16}$

Recent studies appear to confirm that associations in developed economies do, indeed, use the aforesaid strategies to maintain some level of harmony among their diverse memberships - and experience mixed results. ${ }^{17}$ But there is, as yet, no empirical study, which conducted an in-depth investigation into the way that business associations in developing countries deal with the diverse logics that exist within them from the top down; we have, hitherto, little indication of whether the approaches of associations in developing economies would be similar to (or different from) associations in developed economies. The aim of this paper is to lead the way, on this front, by presenting a case study of the four most prominent peak national business interest associations in Sri Lanka - the focus of which is on the attempts of these association's leaders at reconciling the diverse voices and interests of their members. The choice of Sri Lanka is driven by the reputation that Sri Lankan business associations have for being an effective vehicle for private sector representation. ${ }^{18}$ It is also motivated by the lack of research on business interest associations in South Asia, despite the region's increasing prominence in the global economy today.

We find that insights from contemporary institutional logics literature ${ }^{19}$ are particularly helpful in explaining the strategic and structural means, ${ }^{20}$ by which Sri

\footnotetext{
${ }^{13}$ e.g. Bowden, 1999; Schmitter \& Streeck, 1999; You \& Barry, 2016

${ }^{14} 1999$

$151965 ; 1982$

16 also see Unger \& van Waarden, 1999

17 e.g. You, 2016; You \& Barry, 2016

${ }^{18}$ Moore \& Hamalai, 1993; c.f. say, Kadin in Indonesia per Hicks, 2012; also Hartono, 2011

${ }^{19}$ see $\mathrm{Yu}, 2015$

${ }^{20}$ per Greenwood, Raynard, Kodeih, Micelotta and Lounsbury, 2011
} 
Lankan business associations address the issue of presenting a united front for the very diverse group of firms and industries that make up their membership. Specifically, our observation shows that Sri Lanka's peak business associations respond to the diverse, and at times competing, interests of its members in ways that are consistent with Kraatz and Block's ${ }^{21}$ characterisation of organisational responses to institutional complexity, namely through: elimination/marginalisation, mediation, compartmentalisation and detachment.

Organisational institutionalist concepts have, in the past, been effectively used to explain business association behaviours in advanced industrialised economies. Sheldon, Nacamulli, Paoletti and Morgan, ${ }^{22}$ for example, convincingly argue how resource dependency and strategic choice theories help to explain the interaction between leading Italian and Australian business associations, and the environment in which they operate. Our study shows how insight from yet another part of organisational institutionalist discipline, namely institutional logics, can also be applied to understand business association behaviours, structures and identities. This is the theoretical contribution that we make in this paper.

Our practical contribution is to show how a collective organisation, like a business association, can proactively manage institutional complexity from the top down, through the use of processes and structures. ${ }^{23}$ We illustrate what these processes and structures look like, in practice, by detailing the way that Sri Lankan business associations incorporate them into their organisations. Finally, we demonstrate how, by doing this, Sri Lankan business associations are consequently able to garner support for, and build consensus around, a prioritised selection of the most important policy issues that affect them and their members.

\section{Business Interest Associations and Institutional Complexity}

A considerable challenge faced by many membership organisations, including business interest associations, is reconciling the interests and voices of a diverse group of members (Barnett, 2013; Bowden, 1999; Mortimer, Bain \& Bond, 2004; Moore \& Hamalai, 1993; Önis \& Türem, 2001). Indeed, institutional works ${ }^{24}$ performed by members of business associations are often in pursuit of goals that are inconsistent with those of other members. Divergence of interests between members are especially prominent in associations that have a broad appeal like the

\footnotetext{
${ }^{21} 2008$

222014

${ }^{23}$ as suggested in Greenwood et al, 2011; Kraatz \& Block, 2008

${ }^{24}$ Lawrence \& Suddaby, 2006
} 
various chambers of commerce in Sri Lanka. While these associations are theoretically meant to represent the common interests of all its members and driven by the logic of collective activity, ${ }^{25}$ the reality is that businesses very often want different things. For instance: those seeking to expand trade to international markets, like Sri Lanka's large plantations and tourism operators, support liberal economic policies; those who fear competition from abroad in the domestic market, like the country's chemical manufacturers and garment producers on the other hand, seek industry protection which runs counter to liberal economic policies. ${ }^{26}$

In Sri Lanka, the key issues that divide businesses often revolve around trade and industry policy (specifically, around how open Sri Lanka should be to international trade). But observation from other countries suggest that conflicts between members can also be internally focused, for example between larger and smaller members (Perry, 2008; also see Barnett, 2013). Mortimer, Bain and Bond (2004); You (2016); and You and Barry (2016) presented an in-depth narrative of such struggle in the Australian Retailers Association. On the one hand are larger members, who expect their association to perform more lobbying activities; on the other, smaller members who expect more services like a business advisory phone line and assistance with creating various business contracts.

Literary works of American authors, such as Olson $(1965 ; 1982)$ and Barnett (2013), would lead one to think that larger members would simply be able to steamroll their agenda into the broader positioning of their collective associations - thus quickly ending the conflict. But this did not materialise in the aforementioned Australian example, and the conflict between larger and smaller members persisted. Conflict among members of an association can also revolve around ideological positioning as documented in Bowden ${ }^{27}$ and (to an extent) You and Barry. ${ }^{28}$ These conflicts can even prompt a schism and the consequent creation of new associations to compete against those that are already established. ${ }^{29}$

Literature on institutional logics presents useful insights on the various mechanisms for mediating diverse interests and logics, which presents a great starting point to answering the question of how collective organisations can develop effective ways to address the plurality of interests that is characteristic of business interest association. Much of the literature on organisational responses to institutional

${ }^{25}$ Bennett, 2000; Streeck \& Schmitter, 1985; Schmitter \& Streeck, 1999

${ }^{26}$ Jayawickrama, 2004

${ }^{27} 1999$

${ }^{28} 2016$

${ }^{29}$ You \& Barry, 2016; e.g. in Sri Lanka, as documented by Jayawickrama, 2004 
complexity and diversity, however, focus on the way organisations address these issues from the bottom-up rather than strategically from the top-down. ${ }^{30}$

Nonetheless, there is a body of literature within the institutional logics stream of research that provide a helpful framework for analysing and understanding the ways, in which business associations can address issues associated with the diversity of interests among their members from the top-down. Greenwood, et $\mathrm{al}^{31}$ suggest that leaders of an organisation can respond to institutional complexity, arising from the diversity of logics, through the use of structures and strategies. Kraatz and Block ${ }^{32}$ note that management can mitigate issues associated with institutional diversity by way of marginalisation, mediation, compartmentalisation or detachment.

Similarly, Pratt and Foreman ${ }^{33}$ proffer four strategic approaches to dealing with institutional plurality, with a focus on how it shapes an organisation's identity. They are: deletion, aggregation, compartmentalisation and integration. Here, the notion of deletion is comparable to Kraatz and Block's ${ }^{34}$ 'marginalisation' and 'detachment' strategies. Aggregation and integration are comparable to 'mediation' - and the term 'compartmentalisation' is defined by the two texts in a similar way.

As to what identity an organisation ultimately takes ${ }^{35}$, or which strategy is ultimately chosen to respond to institutional complexity, ${ }^{36}$ this largely depends on the political power, will and resources of each actor, or faction, in its leadership. ${ }^{37}$ Our empirical study presents support for this notion.

The organisational institutionalist literature we have discussed thus far present helpful tools with which to study collective associations' responses to institutional complexity and pluralism. Indeed, institutional logics theory has frequently been used to understand collective organisations like trade unions, ${ }^{38}$ professional groups ${ }^{39}$ and sports clubs. ${ }^{40}$ But we are yet to see empirical studies that apply these

\footnotetext{
${ }^{30}$ e.g. Reay \& Hinnings, 2009

312011

322008

332000

342008

35 per Pratt \& Foreman, 2000

36 per Kraatz \& Block, 2008

37 see Fleming \& Spicer, 2014; Pratt \& Foreman, 2000; Yu, 2013; also Greenwood et al, 2011

${ }^{38} \mathrm{Yu}, 2013$

${ }^{39}$ Lounsbury, 2007

${ }^{40}$ Gammelsaeter, 2010
} 
concepts to business associations in developing economies. ${ }^{41}$ Our research seeks to address this gap in the literature.

\section{Research Question and Methodology}

Our empirical study seeks to understand how business interest associations in a developing country can successfully manage institutional pluralism in their organisations. Our approach is that of a case study on peak business interest associations in Sri Lanka. The choice of Sri Lanka is driven by the reputation that its business associations have for being an effective vehicle for private sector representation. ${ }^{42}$ Sri Lankan associations are well recognised for their considerable contribution to the country's business community and the economy as a whole. ${ }^{43}$ They demonstrate strong leadership in corporate social responsibility, ${ }^{44}$ and their longevity and reputation are notable given the considerable challenges faced by many associations to their institutional survival. ${ }^{45}$

Sri Lanka hosts a large number of business interest associations. But only a few are of interest to the present study. Our investigation requires data to be gathered from only the largest peak associations because small and specialised associations tend to have very narrow sets of interests and goals, and rarely get involved in matters that are not directly relevant to their particular sectors. ${ }^{46}$ Broad interest representation is critical to the research project, given the nature of our investigation - consequently, we have approached only the four leading associations in the country. These are: the Ceylon Chamber of Commerce ('CCC'), the Employers Federation of Ceylon ('EFC'), the National Chamber of Commerce of Sri Lanka ('NCCSL'), and the Ceylon National Chamber of Industries ('CNCI').

The research question at the centre of our empirical analysis is: "How do Sri Lanka's leading business interest associations manage the diversity of interests among their memberships?"

To answer this question, we collected, assessed and analysed relevant documentary data which were written about, or by, the aforementioned associations - whether

41 The application of concepts from organisational institutionalism on the study of business associations is not new (e.g. Sheldon et al, 2014). But our study is the first to apply concepts specifically from the institutional logics stream of literature on business associations that operate in a developing economy.

${ }^{42}$ Moore \& Hamalai, 1993

${ }^{43}$ e.g. DailyFT, 2011; c.f., say, Indonesia’s associations - per Hicks, 2012

${ }^{44}$ DailyFT, 2016; Hatton Bank, 2015

${ }^{45}$ e.g. Fashoyin, 2008

${ }^{46}$ see Barry \& You, 2017; You, 2016 
they be publicly available or provided to us directly by the associations; and we conducted face-to-face interviews with senior leaders of each of the associations. Each interview was performed by the first author in either the head office of the association, the head office of the interviewee's firm (where the interviewee is not an employee of the association's secretariat body ${ }^{47}$ or the interviewee's residence - each of which took between 45 and 90 minutes, and all of which took place in greater Colombo between August and September of 2015. ${ }^{48}$ Every interview was recorded and transcribed - and conducted in English. The use of English for the purpose of this project is appropriate because English serves as Sri Lanka's the de facto language of business administration. ${ }^{49}$ Expectedly, every interviewee speaks English fluently.

This approach to empirical investigation is dubbed 'elite interviewing', ${ }^{50}$ whereby the researcher targets the most senior leaders of the organisations of interest to provide input to the study. The logic behind this is that people at the head of an organisation are privy to information that other, more junior, members of the organisation are not. Consequently, they are more likely to be able to provide the data we need to answer our research question. People in senior leadership also feel less restrained in providing responses to interview questions posed by a researcher, especially when they are not anonymised. Consequently, our approach is appropriate for the present study - and the reason for why comparable studies on business associations in other countries also approach data collection in the same way. ${ }^{51}$

\section{Limitation}

A key limitation, arising from the chosen methodology, is that it does not capture the views and responses of non-executive members vis-à-vis their associations' approach/es to managing institutional diversity within it. Our interviews do capture

\footnotetext{
47 An association's secretariat function consists of professionals employed directly by the association as an entity, to manage its day-to-day operations and receive instructions from members. The highest-ranking member of the secretariat of an association is usually given the title Chief Executive, Secretary General or Executive Director. They report to the management committee (or council or board), which consists of elected members of the association. Members of the management committee are not paid staff of the association body.

${ }^{48} \mathrm{We}$ provide a list of informants in the appendix

${ }^{49}$ Amerasinghe, 2009

${ }^{50}$ Flick, 2014; Richards, 1996; Trochim, 2006; Welch, Marschan-Piekkari, Penttinen \& Tahvanainen, 2002

${ }^{51}$ e.g. Faisal, 2013; Sheldon et al, 2014; Sheldon, Nacamulli \& Paoletti, 2009; You, 2016; You \& Barry, 2016
} 
the views of members, and not just secretariat leaders, but these members are elected representatives with official leadership duties. Consequently, our research question cannot capture the feeling of what it is like to be an association member whose views are not aligned with the position of their association, ${ }^{52}$ thus our focus on the way in which diversity of interests is managed, from the top-down, by the business association leadership.

\section{Peak Business Interest Associations in Sri Lanka}

The establishment of the first island-wide business chamber in Ceylon, i.e. the $\mathrm{CCC}$, was instigated by British plantation owners during the colonial era prior to the turn of the 20th Century (Jayawickrama, 2004). The process is comparable to the emergence of business associations in the West (see Windmuller \& Gladstone, 1984 ) in that powerful commercial actors from key industries came to associate, under a single banner, for the purpose of voicing their collective interests and concerns to public authorities (Jayawickrama, 2004; M Yapa, interview; K Weerasinghe, interview). The founders of the CCC additionally sought to utilise the association as an institution that regulates the relationship between commercial establishments in the colony.

The desire for an independent body to oversee labour and industrial relations, early in the new (20th) century, later resulted in the creation of the EFC - initially under the auspices of the CCC. The activities of the CCC and EFC were primarily driven, and their agenda dominated, by the collective interests of British commercial establishments. Eventually, however, indigenous businessmen (and later women) began to play a greater role in their management and operation (Jayawirckrama, 2004; K Weerasinghe, interview).

But for many prominent Ceylonese business leaders, greater representation in what remained essentially a British-dominated chamber was unsatisfactory. There was a sense that indigenous businesses should be represented by a separate chamber body that is led by local Ceylonese entrepreneurs. This culminated in the formation of the Ceylon National Chamber of Commerce ${ }^{53}$ just after Ceylon's independence from the United Kingdom in 1948. A further 'split' in the CCC in 1960 resulted in

\footnotetext{
52 Future research seeking to address our limitations would benefit from considering the research method used by Spooner (2004) to capture the sentiments of members broadly.

53 Later NCCSL. Replacing the British designated term 'Ceylon' with 'Sri Lanka' after the country became a republic (Lanka being the traditional name of the island with the honorific 'Sri' added to it) sends a message that the chamber is run by and for local business interests.
} 
the creation of the $\mathrm{CNCI}$ - primarily to represent the interests of manufacturers and sectors that benefit from high industry protection.

The Ceylonese/Sri Lankan ${ }^{54}$ government instigated the creation of the Federation of Chambers of Commerce and Industry Sri Lanka ('FCCISL') in the early 1970s. Its aim was to be an apex body that represents the country's various business associations under one banner and be a single medium of communication between the government and business community. But the federation project failed and instead of creating a united apex representative body, the FCCISL just became yet another association competing for government influence (A Muthugala, interview; $\mathrm{C}$ Vithanage, interview; F Amerasinghe, interview). It is now largely inactive (A Muthugala, interview; FCCISL, 2015).

Without counting the FCCISL, as at the time of data collection, there were four active major peak umbrella business interest associations representing Sri Lanka's business community at the national level (see Table 5.1: Peak Business Associations in Sri Lanka below), namely the CCC, EFC, NCCSL and CNCI. These associations vary in size and revenue intake. The largest, by membership coverage, income and secretariat functions, is the CCC, which employs around 100 secretarial staff (C Vithanage, interview) and collected a gross revenue of Rs 247 million $^{55}$ in the 2014/15 financial year (CCC, 2015a). ${ }^{56}$ The largest by total asset is the EFC with Rs550 million (EFC, 2014). ${ }^{57}$

Peak Business Associations in Sri Lanka

\begin{tabular}{|l|l|l|l|l|}
\hline Peak National BIA & CCC & EFC & NCCSL & CNCI \\
\hline Founded & 1839 & 1929 & 1948 & 1960 \\
\hline Chair/President & Suresh Shah & $\begin{array}{l}\text { Susantha } \\
\text { Rathnayake }\end{array}$ & $\begin{array}{l}\text { Thilak } \\
\text { Godamanna }\end{array}$ & $\begin{array}{l}\text { Gamini } \\
\text { Gunasekera }\end{array}$ \\
\hline Chair's Org & Lion Brewery & John Keels & Ninehearts & Union Chemical \\
\hline CEO & Mangala Yapa & $\begin{array}{l}\text { Kanishka } \\
\text { Weerasinghe }\end{array}$ & $\begin{array}{l}\text { Bandulla } \\
\text { Dissanayake }\end{array}$ & $\begin{array}{l}\text { Abeyratne } \\
\text { Muthugala }\end{array}$ \\
\hline
\end{tabular}

${ }^{54}$ Ceylon changed its name to Sri Lanka in 1972.

${ }^{55}$ US\$ 1.64 million (approx.. AU\$ 2.14 million).

${ }^{56}$ For the year ended 31 March 2015.

57US\$3.66 million (approx. AU\$ 4.78 million) as at 31 March 2014. 


\begin{tabular}{|l|l|l|l|l|}
\hline Focus & $\begin{array}{l}\text { Trade and } \\
\text { Commerce }\end{array}$ & $\begin{array}{l}\text { Industrial } \\
\text { Relations }\end{array}$ & $\begin{array}{l}\text { SME } \\
\text { Development }\end{array}$ & $\begin{array}{l}\text { Industry } \\
\text { Protection }\end{array}$ \\
\hline
\end{tabular}

Table 5.1: A Summary Profile of Peak National Business Interest Associations in Sri Lanka as at 2015

\section{Sri Lankan Business Associations' Response to Institutional Pluralism}

Our analysis of the empirical data from the research project identified five ways, in which Sri Lanka's peak business associations address institutional pluralism that exist among their memberships.

\section{Facilitating Self-advocacy}

The first is by providing support for individual members, or the various factions of their memberships, to promote their own private interests to policy makers. Sri Lankan associations frequently facilitate direct communication between individual members and key public figures as opposed to standing as a medium of communication between them. ${ }^{58}$ An example of how this is done is by holding a round-table discussion on a topical issue with key decision makers in government (e.g. department heads and government ministers), in which all members are invited to participate and directly voice their desires and concerns. This allows the diverse logics within the association to have equal opportunity to be represented, and avoids its management committee from having to reject one policy position in favour of another at times when there are competing views among its members.

Any individual member, or faction of membership, which does not participate in such forum cannot blame the association for not giving them the opportunity to promote their own interests and direct their grievances to the government. Additionally, any outcome that is unfavourable to any particular member similarly cannot be blamed on the association - as the association already provides the avenue for that member to argue their case directly to the government representative/s.

Giving an example of how the NCCSL approaches a proposed Indo-Sri Lankan Comprehensive Economic Partnership Agreement, CEO Bandulla Dissanayake noted:

${ }^{58}$ M Yapa, interview; K Weerasinghe, interview; G Gunasekera, interview; A Muthugala, interview 
So we organised [a] very good debate, here in this place, at our auditorium in the next room. And we invited the government also to come, and the minister for policy planning also was there ... They actually gave us a very good hearing, so it was a very balanced discussion. People who were supporting and opposing were there, and even the minister himself was there with all his senior officials like the department of commerce, export development, bureau, etcetera. All responsible for trade facilitation in the country.

It was a very good debate and we managed to communicate what the business community was telling, as a whole, to the government. So these are the deliberations or rather things that we want to communicate and there was a special way that we communicate. So this is how we come up with what is needed by the business community and we communicate like this. Like my chairman said, we take a lot of other discussions also.

Recently, we had a construction industry related issuesv- serious discussion! There we had all construction development authority in the country representing their case and we brought in all construction industry people to one floor and we had a very good discussion.

This practice is consistent with the notion of addressing institutional complexity ${ }^{59}$ through strategic means. ${ }^{60}$ Specifically, the forums act to both 'eliminate tensions' derived from such complexity and, at the same time, "strive to balance the various institutional demands by increasing cooperativeness among [different] identities and forging links among them". ${ }^{61}$ They do so by providing space for competing logics to work around their differences, while pushing aside the voices of those who do not commit to attending these meetings.

\section{Utilising Formal and Informal Organisational Processes}

In addition to holding these round-table discussions, Sri Lankan business associations also have more traditional means for addressing issues arising from their members' competing interests - namely in the form of extensive rules and conventions, enforced by elected members of the management committees. For the most part, their articles of association and various by-laws stipulate that the views of the majority be adopted, but with those holding alternative positions be given the

\footnotetext{
${ }^{59}$ Or pluralism or diversity

${ }^{60}$ Greenwood et al, 2011

${ }^{61}$ Greenwood et al, 2011; p. 349; Kraatz \& Block, 2008; also Binder, 2007
} 
opportunity to argue their points in a members-only/committee forum, in which they would seek to persuade management committee members (and opposing factions) of the validity of their positions.

Where individual, or a faction of, members disagree with the positioning of the majority, they are at least given a chance to argue their case and are provided reasoning for the position that the association ultimately takes. ${ }^{62}$ This process is not only aimed at giving members a sense of procedural justice, but also a cognitive understanding of the position that the association takes on particular issues. In turn, this mitigates the risk of a major fall-out between membership factions.

An example of one such mechanism is provided by cls. $38-45$ of the Rules of the Ceylon Chamber of Commerce regarding Committee Meetings, which allows for any association member to requisition a committee meeting (under cl. 38(i)) ${ }^{63}$ for the purpose of bringing up a grievance in the form of a 'matter' to be settled by the management committee. In this instance, cl. 41 of the rules state that the matter "shall be decided by a majority of votes" - assuming that a quorum of at least 25 committee members are present (cl. 39). Other avenues to air out grievances include the general meeting of ordinary members (cl.49(i) $(\mathrm{g})$; cl.53).

The organisational rules and processes, used for this purpose, are not necessarily formal and structured, though it is often the case. We observe that while large associations like the CCC and EFC have detailed written procedures, as well as formal and documented committee meetings, smaller associations like the CNCI relies more on informal, institutionalised practices and conventions to bring to surface competing logics in order to address associated issues through procedural means. ${ }^{64}$ Regardless of the formality of the procedures employed, what we discussed under this sub-heading is reminiscent of Greenwood et al's ${ }^{65}$ structural approach to addressing institutional complexity, whereby facets of the organisation's structural make-up are utilised to manage competing voices.

\section{Deploying Affiliate Organisations}

Despite their best efforts, however, there are conflicts between association members (or factions of their memberships) that are simply irreconcilable - because their differences exist at a fundamental level. An example of this is regarding the debate surrounding trade policy. Any position taken by the association body, whether to

\footnotetext{
${ }^{62} \mathrm{C}$ Vithanage, interview; $\mathrm{K}$ Weerasinghe, interview

${ }^{63}$ given they've got adequate support from sitting committee members

${ }^{64} \mathrm{G}$ Gunasekera, interview

${ }^{65} 2008$
} 
support or oppose open market policies, is likely to marginalise a considerable section of its membership - and there is little room for nuance on the matter. ${ }^{66}$

To deal with such tough issues in which disagreements fall along industry line, major nation-wide chambers, like the CCC and NCCSL, utilise their large, decentralised affiliate networks to their advantage. The CCC's Senior Assistant Secretary General, Chandraratne Vithanage, explains it thus in our interview:

[S]ay, the hotel sector is asking for duty free [i.e. for the chamber to promote liberal economic policies]. [But] the garment sector is also with us. How can garment - garment can't accommodate all of this! So, it's not realistic.

But ... all these different sectors have their own bodies now. As doctors have their own, you know, doctors, nurses engineers have their own likewise. Each and every trade has their own traders' association. Rubber traders association, coconut traders association, tyre traders ... So, they, if they have that kind of individual cases [that are inconsistent with the CCC's official position], then they take it [i.e. to their association, for the industry body to advocate].

The affiliate structures of associations like the CCC allows for positions of conflicting factions to be advocated and represented by their respective affiliate bodies, which still reside under the umbrella of the peak body. In this way, multiple sides of a conflict can be accommodated regardless of the position of the peak body itself. The peak association is still able to claim broad support, however, when it comes to lobbying on a few broad national issues which members uniformly support (e.g. corruption eradication and infrastructure development), despite its affiliates having conflicting positions on other matters.

Moore and Hamalai ${ }^{67}$ suggest that this is a sign of weakness on the part of peak Sri Lankan associations and a sign that their role in advocating the interests of their members is secondary to that of their industry affiliates. But we argue to the contrary and that the mobilisation of industry and regional affiliates by broad interest chambers, to represent the interest of their specific constituents, are indeed intentional - and forms a part of a conscious strategy to manage different interests that the peak, broad interest chambers seek to represent under their one banner.

${ }^{66}$ c.f. Thurbon, 2016

${ }^{67} 1993$ 
This approach is consistent with Kraatz and Block's ${ }^{68}$ depiction of institutional 'compartmentalisation', in which an organisation "attend[s] to different institutional claims ... by creating separate units and initiatives that demonstrate its commitment to the values and beliefs of particular constituencies". Alternatively, this approach can also be characterised as a 'structural' (as opposed to strategic) response, by which "separate subunits deal with particular logics, essentially [through] partitioning / compartmentalizing an organization into different mindsets, normative orders, practices and processes. ${ }^{69}$ By compartmentalising the peak chamber body into smaller affiliate sub-units, broad interest chambers like the CCC and NCCSL lessen the risk of internal factional conflicts developing into a schism which threatens the integrity and survival of the association body. Additionally, they can continue to claim the support of these competing factions on a selection of key national issues, in which its members all have in common (e.g. political transparency, improving government accountability, placing GDP-per capita growth at the top of government priorities, etc.).

\section{Rallying Around an Ideological Cornerstone}

Compartmentalisation works because it is much easier for industry and regional associations to rally their members around their typically narrower agenda than it is for broad interest associations to garner support around national issues. But this is not to say that compartmentalisation is needed by all associations that operate at the national level. The CNCI is able to unite its members without compartmentalisation through the use of affiliate bodies. The reason is because the association is quite small and has traditionally been driven by a more specific set of agenda than those of the aforementioned larger chambers. The underlying logic of these agenda unites its membership.

Although the CNCI formally claims to have the interest of the nation as a whole as its first priority, as do all other associations studied in this project, the chamber is clearly driven by the interests of local manufacturers, ${ }^{70}$ first and foremost. These firms uniformly benefit from regulatory restrains against the free market because Sri Lankan manufacturers cannot naturally compete against those, who are based in countries like India and China. ${ }^{71}$ It follows that the association is also sceptical

\footnotetext{
${ }^{68} 2008$, p.259

${ }^{69}$ Greenwood et al, 2011; p. 354; also Kraatz \& Block, 2008

${ }^{70}$ And foreign-owned manufacturing firms, which operate in Sri Lanka and seek to serve Sri Lanka's domestic market

${ }^{71}$ Sri Lankan manufacturers simply do not enjoy the economies of scale that Indian and Chinese manufacturers tend to enjoy due to the smaller size of their main (domestic) market
} 
about the notion of the free movement of labour. CNCI's Secretary General Abeyratne Muthugala explains it thus:

India is a huge country, where the population is - as far as the population is concerned, it is over 50 times the population of the country. More than 100 million, population is there. Sri Lanka, only ... 20 million ... India actually is almost ... 1.2 billion, yes? So as far as unemployment population is concerned, that unemployed population is more than the total Sri Lankan population, right? So, it's a huge threat to the, to the Sri Lankan unemployed people, no?

And on the other hand, as far as the, the information technology is concerned, India is quite advanced. There are a lot of people who are quite competent in information technology, who are without jobs. So due to this, this reason, some chambers are not believe to get [free trade agreement] with India. They're against it. But some chambers like the Ceylon chamber of commerce, they like it. They want to get the, the agreement to be effected.

Sri Lankan manufacturers were the founders of, and form the most powerful group in, the CNCI. Consequently, promoting the collective interests of the manufacturing industry has become the cornerstone of the chamber's activities and criterion against which the merit of competing arguments in policy debates are internally evaluated. ${ }^{72}$

CNCI Chairman Gamini Gunasekera explains:

Now the concept is: Suppose you want to import my material - what I manufacture locally. You want [to] import the chemical that I manufacture locally. You are asking to remove all the duty. I am asking "No, put duty here! Protect my industry [from] competitors!" You are trader. You import and manufacture. But both are members of CNCI. But CNCI support manufacture! We are itself with the manufacturing - right? We explain [to] him, "Sorry we cannot support you bring your trade. You are also manufacture. We support you, ok?" [If they said,] "Ok, I don't want to be." [Then] Ok, you can get out from membership.

This approach exemplifies Kraatz and Block's ${ }^{73}$ resistance/elimination strategy to dealing with institutional pluralism, whereby organisational practices act as a filter

\footnotetext{
${ }^{72}$ A Muthugala, interview; G Gunasekera, interview
}

${ }^{73} 2008$ 
to prevent competing logics from joining and thus creating conflict in the organisation.

Other Sri Lankan associations similarly have a set of dominant values that act as cornerstones to their positions, adherence to which is enforced by the entire active membership at committee elections, policy forums and annual general meetings. ${ }^{74}$ But these values tend to be broader, vaguer and not as uncompromising as that of CNCI's. For the CCC, for instance: ${ }^{75}$

[W] hat we say is, nation first. Those are the core values. Nation first, then ... the sectoral interests. And then ... say there's a pretty big individual company who has, who is lobbying for something. But if it's only benefiting that company, that will be the last. You know, business interest is the last. First were national interest, sectoral interest and last is the individual interest.

The interpretation of the term 'national interest' by the CCC usually aligns with expansionary and liberal economic policies; but as Vithanage's earlier remark suggests, this position is not unnegotiable and largely depends on the positions of the management committee from time to time. This approach is also adopted by the NCCSL. ${ }^{76}$

As for the EFC, given the relatively narrow focus of the association on employment and industrial relations, intra-association conflicts of interest among its members are reportedly rare. After all, and as far as employment regulations are concerned, employers in the developing world generally want similar things: cordial relations with unions (assuming that they cannot be totally shut-down); labour market flexibility; improved labour productivity; simple, clear and easy-to-understand labour regulations; and the like. Furthermore, firms that join the EFC are driven by the logic of membership more so than the logic of collective action ${ }^{77}$ - meaning that firms do not so much look to the EFC for collective representation as they do for collective and elective services. ${ }^{78}$ This is evidenced by the great deal of reliance that EFC members' place on the secretariat functions when it comes to collective advocacy and policy positioning. ${ }^{79}$

\footnotetext{
${ }^{74} \mathrm{~K}$ Weerasinghe, interview; M Yapa, interview

75 as per interview with $\mathrm{C}$ Vithanage

${ }^{76}$ B Dissanayake, interview; T Godamanna, interview

${ }^{77}$ Schmitter \& Streeck, 1999

${ }^{78}$ see also Sheldon \& Thornthwaite, 2004; You, 2016

${ }^{79} \mathrm{~F}$ Amerasinghe, interview; K Weerasinghe, interview
} 
Consequently, conflicting interests between members rarely come to surface in the $\mathrm{EFC}$ - and when they do, they are adequately addressed through mediation by the secretariat or by the latter providing an avenue for conflicting parties to have their voices heard directly by policy makers in an open forum. ${ }^{80}$ In this way, the EFC is able to largely avoid intra-organisational conflicts - and prevent ones that do arise from spinning out of control. For its chamber counterparts, however, these conflicts are at times not just unavoidable but also uncontainable - despite the aforesaid mechanisms developed to address them. This is further discussed below.

\section{Splitting Up}

Differences in ideas and interests among members of a business interest association can result in a schism, whereby a section of association membership splits to form a new association to accommodate their factional interests, which the 'parent' association is unable, or perceived to be unwilling, to accommodate. ${ }^{81}$ This is consistent with the notion of 'detachment' under Kraatz and Block's typology of organisational response to institutional complexity. Major splits have occurred a number of times in the history of the CCC, Sri Lanka's largest and oldest business association. Irreconcilable differences between factional groups in the chamber, soon after Ceylon's independence, resulted in schisms that prompted the creation of the Ceylon National Chamber of Commerce ${ }^{82}$ and CNCI in 1948 and 1960 respectively.

The CNCI was created because Ceylonese manufacturers were dismayed at what they perceived to be the domination of the main business chamber (i.e. the CCC) by large importers and exporters, who oppose the protectionist policies of Sri Lanka's Bandaranaike government in the late 1950s. The founding members of the fledgling chamber, at the time, were "small timers ... [who] had to pit their wits against big trading organizations [in the CCC, where] ... industry in Sri Lanka during that era was viewed with a condescending attitude" ${ }^{83}$ The CCC attempted to contain the discontent by way of compartmentalisation (i.e. through the creation of the Ceylon Association of Manufacturers under its auspices). But by then, it was too late. Ceylonese manufacturers believed that their interests and those of the CCC's leading members were so irreconcilable that they needed nothing short of

\footnotetext{
${ }^{80} \mathrm{~K}$ Weerasinghe, interview; A Fernando, interview

${ }^{81}$ also explored in You \& Barry, 2016

82 The predecessor of the NCCSL

${ }^{83} \mathrm{CNCI}, 2016$
} 
an independent association of their own. ${ }^{84}$ Affiliation with the CCC, therefore, was unsatisfactory for them.

Like the CNCI, the predecessor of the NCCSL also 'split up' from the CCC in response to what was perceived to be the CCC's underwhelming response to the plight of some of its constituents. ${ }^{85}$ At around the time of its creation, there was significant imbalance in the economic powers of local, indigenous businesses compared to those of British owned firms. ${ }^{86}$ This was partly the result of imbalance in the structural and institutional support available to Ceylon's businesses and entrepreneurs. For instance, the Ceylon Banking Commission Review of the mid 1930s found "that there were serious shortcomings in access to credit, especially for Ceylonese ${ }^{87}$ entrepreneurs". ${ }^{88}$ Additionally, the commercial banking system at the time was dominated by foreign banks which were almost exclusively engaged in the financing of foreign owned plantations and import-export businesses. ${ }^{89}$

The CCC has been instrumental in promoting the development of structural and institutional support for Ceylon's commercial landscape since its inception in 1839. But much of their early efforts have been targeted in favour of British-owned firms. There was a shortage of support specifically for indigenous small to medium sized enterprises ('SMEs') - and by the mid-1940s, they grew increasingly frustrated at what they perceive to be the CCC's inaction to address this issue. ${ }^{90}$ Ceylonese businesses additionally wanted mandated "government preferences in relation to European firms", ${ }^{91}$ which did not sit well with the CCC many of whose members were European owned.

The CCC did eventually seek to address its local members' grievances and even underwent a period of 'Ceylonisation', during which time "the complexion of the Chamber began to change" 92 - quite literally. But this was not enough to contain the discontent of indigenous SME members, who were determined to establish an association of their own, independent of the CCC.

\footnotetext{
${ }^{84}$ Jayawickrama, 2004; Moore \& Hamalai, 1993; G Gunasekera, interview

${ }^{85}$ Moore \& Hamalai, 1993; T Godamanna, interview

${ }^{86}$ Amerasinghe, 2009; Jayawickrama, 2004

87 i.e. native or local, non-British

88 Jayawickrama, 2004, p.69

${ }^{89}$ CBSL, 1990

90 T Godamanna, interview; B Dissanayake, interview

${ }^{91}$ Moore \& Hamalai, 1993, p.1907

92 Jayawickrama, 2004, p.70
} 
The CCC today competes for members, and in the policy arena, with the NCCSL and CNCI. But this competition notably takes place "without overt rancor". 93 Despite competing with one another, the relationship between these associations is cordial $^{94}$ and in none of our interviews was there a sense of animosity between competing associations. ${ }^{95}$ Evidence suggests that the cordial attitude is genuine and that the CNCC's and CNCI's splits from the CCC did not produce lasting hostility or animosity among the chamber executives and organisations. The various chambers commonly collaborate on development and capacity-building projects throughout Sri Lanka. ${ }^{96}$ There are even times when representatives of firms served in the management committee of both the CCC and NCCSL simultaneously - e.g. Segarajasingham Nagendra of Travelserv ${ }^{97}$ in the mid 1980s. ${ }^{98}$

Paradoxically, You and Barry ${ }^{99}$ suggest that the split in large peak associations like the CCC could have contributed to warming relations between key, active members of the 'parent' 100 and newly established associations. They note that although ideological differences between associations may have a negative effect on their relationships, this is moderated by market segmentation between them. In other words, inter-association rivalry is less intense between associations which target different types of members than those which seek to represent similar firms. When a faction of a large association splits to form another association and "emerge as "institutions in their own right,", 101 in response to institutional complexity, their membership is likely to differ considerably to that of the parent association. For this reason, animosities between association leaders must eventually subside.

\section{Discussion and Conclusion}

This paper is a response to a call by Lawton, Rajwani and Minto (2018) for contemporary academic contributions to insights on the way that business interest associations function. Business associations are important actors in the political and economic landscape of a country. But empirical and academic research on their

\footnotetext{
${ }^{93}$ Moore \& Hamalai, 1993, p.1907; also Jayawickrama, 2004; c.f. inter-association rivalries depicted in Bowden, 1999; You \& Barry, 2016

94 Jayawickrama, 2004; T Godamanna, interview; M Yapa, interview; G Gunasekera, interview

95 c.f. say, Bowden, 1999; You \& Barry, 2016; You, 2016

${ }^{96} \mathrm{C}$ Vithanage, interview; M Yapa, interview; B Dissanayake, interview; T Godamanna, interview

${ }^{97}$ Who subsequently served as Chairman of the CCC in 1987.

${ }^{98}$ Moore \& Hamalai, 1993

992016

${ }^{100}$ Or 'original' for lack of a better term

${ }^{101}$ Greenwood et al, 2011, p.354
} 
activities and internal make-up are few and far between. This paper seeks to address this gap.

The primary purpose of a business interest association is to represent the collective interests of its members. Business associations are meant to unite the voices of the business community, and express the views and opinions of the private sector in policy debates. The underlying logic behind their existence is to achieve things that firms in the private sector cannot achieve on their own, as individuals. But representing the interests of the business community is a difficult task - on account of the fact that individual firms very often want different things. This is particularly true for broad-interest associations which operate at the national level.

The dilemma faced by broad-interest business associations in representing a diverse group of members under a single banner, is relatively well documented in developed, industrialised economies. Scholars like Bowden, ${ }^{102}$ Schmitter and Streeck, ${ }^{103}$ and You and Barry ${ }^{104}$ explore the issue in some detail. But there is a gap in empirical literature regarding what associations have attempted, and are attempting, to do to successfully address the issue in developing countries. This is what our study seeks to address.

This paper presents a case study of the way that Sri Lanka's four peak national business interest associations ${ }^{105}$ address the institutional complexity ${ }^{106}$ brought about by the different logics present among their members. Our findings highlight the fact that these associations do not rely on just one particular method, but rather utilise a combination of different approaches to address the aforementioned challenge. Specifically, they:

- Facilitate self-advocacy so as to enable and empower each individual member to speak for themselves and have their voice heard by key policy makers (e.g. government ministers, industry regulators, etc.) through roundtable discussions and forums;

- Utilise organisational processes and structures to mediate differences in opinion among members;

\footnotetext{
1021999

${ }^{103} 1999$

1042016

${ }^{105}$ Namely the CCC, NCCSL, EFC and CNCI

${ }^{106}$ per Greenwood et al, 2011
} 
- Deploy affiliate organisations to advocate the specific interests of particular industries and regions so that the peak body may step aside and avoid getting involved in conflicts between industries and regions;

- Rally their members around a set of common interests and ideological cornerstone which unite them; and should all else fail,

- Split to form another association to represent factions, the interests of which are irreconcilable with the interests and goals of the majority.

These approaches align with Kraatz and Block's ${ }^{107}$ typology of organisational responses to institutional complexity, namely: marginalisation, mediation, compartmentalisation and detachment. They also exemplify Pratt and Foreman's ${ }^{108}$ four strategic approaches to dealing with institutional plurality in organisations, namely by way of deletion, aggregation, compartmentalisation and integration. We discussed the alignments between the abovementioned concepts and our empirical findings in the immediately preceding section of this paper.

It is important to note that the approaches that we've listed above are not unique to Sri Lanka's business interest associations alone. A number of the aforementioned strategies (e.g. facilitating self-advocacy and splitting up) were also observed in recent studies into other membership organisations like retail industry groups in Australia. ${ }^{109}$ This suggests that the findings of the present study may be generalised to business associations that operate other countries - including those that operate in developed nations. Further research is needed, however, in order to confirm this. Furthermore, we suspect that future research regarding the chances of success of the first of the four strategies mentioned above in mitigating the risk of a split would prove worthwhile - as would be additional studies on the impacts of combining different strategies on addressing institutional plurality in business associations.

\footnotetext{
107 2008; also see Greenwood et al, 2011

${ }^{108} 2000$

${ }^{109}$ You, 2016; You \& Barry, 2016
} 


\section{Appendix: List of Interviewees}

Franklyn Amerasinghe

Senior Independent Director at John Keels, former EFC Director General and CEO

Interviewed 28 August 2015 at the Amerasinghe Residence, Wattala

Bandulla Dissanayake

CEO and Secretary General of the NCCSL

Interviewed 20 August 2015 at the NCCSL Head Office, Colombo

Ayomi Fernando

Head of Training at the EFC

Interviewed 5 August 2015 at the EFC Head Office, Rajagiriya

Thilak Godamanna

President of the NCCSL, Managing Director and Chairman of Ninehearts

Interviewed 20 August 2015 at the National Chamber Head Office, Colombo

Gamini Gunasekera

Chairman of the CNCI, Managing Director of Union Chemicals

Interviewed 25 August 2015 at the Union Chemical Head Office, Colombo

Abeyratne Muthugala

Secretary General of the CNCI

Member of the Executive Council of the FCCISL

Interviewed 7 September 2015 at the CNCI Head Office, Colombo

Chandraratne Vithanage

Senior Assistant Secretary General of the CCC

Interviewed 28 August 2015 at the CCC Head Office, Colombo

Kanishka Weerasinghe

CEO and Director General of the EFC

Interviewed 5 August 2015 at the EFC Head Office, Rajagiriya

Mangala Yapa

CEO and Secretary General of the CCC

Member of the Council of the EFC

Interviewed 10 August 2015 at the CCC Head Office, Colombo 


\section{Bibliography}

Acemoğlu, D., \& Robinson, J. (2012). Why Nations Fail. New York: Crown Business.

Amerasinghe, F. (2009). The Current Status and Evolution of Industrial Relations in Sri Lanka. Geneva: ILO.

Barry, M., \& Wilkinson, A. (2016). Pro-Social or Pro-Management? A Critique of the conception of Employee Voice as a Pro-Social Behaviour within Organizational Behaviour. British Journal of Industrial Relations, 54(2), 261-284.

Barry, M., Michelotti, M., \& Nyland, C. (2006). Protectionism, Common Advocacy and Employer Interests: Business Contribution to Labour Market Regulation in Australia. In C. Arup, P. Gahan, J. Howe, R. Johnstone, R. Mitchell, \& A. O'Donnell (Eds.), Labour Law and Labour Market Regulation (pp. 43-66). Sydney: Federation Press.

Bell, S. (1994). Australian Business Associations: New Opportunities and Challenges. Australian Journal of Management, 19(2), 137-157.

Bennett, R. (2000). The Logic of Membership of Sectoral Business Associations. Review of Social Economy, 58(1), 17-42.

Binder, A. (2007). For love and money: Organizations' creative responses to multiple environmental logics. Theory and Society, 36(6), 547-571.

Bowden, B. (1999). Employer associations in road transport. In P. Sheldon, \& L. Thornthwaite (Eds.), Employer Associations and Industrial Relations Change: Catalysts or Captives. St Leonards: Allen and Unwin.

CCD: Community of Democracies Working Group on Poverty, Development and Democracy. (2011). The Role of the Private Sector in Support of Democracy. Washington: Council for a Community of Democracies.

DailyFT. (2011, December 21). CCC wins Global Commerce Excellence Award. DailyFT. doi:http://www.ft.lk/article/61552/CCC-wins-GlobalCommerce-Excellence-Award

Das, S. (2008). Trade Unions in India: Union Membership and Union Density. The Indian Journal of Labour Economics, 51(4), 969-982. 
Doner, R. F., \& Schneider, B. R. (2000). Business Associations and Economic Development: Why Some Associations Contribute More Than Others. Business and Politics, 2(3), 261-288.

Faisal, M. (2013). Democratisation, Business Activism, and the New Dynamics of Corruption and Clientism in Indonesia. International Journal of Social, Behavioural, Educational, Economic, Business and Industrial Engineering, 7(3), 680-689.

Fashoyin, T. (2008). Policy Reforms and Employment Relations in Zambia. Issues Paper No. 29. Harare: Sub-Regional Office for Southern Africa.

Fleming, P., \& Spicer, A. (2014). Power in Management and Organization Science. The Academy of Management Annals, 8(1), 237-298.

Flick, U. (2014). An Introduction to Qualitative Research (5th ed.). London: Sage.

Freeman, R. (2009, March). Labor Regulations, Unions, and Social Protection in Developing Countries: Market distortions or Efficient Institutions? NBER Working Paper No. 14789. National Bureau of Economic Research.

Fukuyama, F. (2014). Political Order and Political Decay. New York: Farrar, Straus and Giroux.

Gallin, D. (2001). Propositions on Trade Unions and Informal Employment in Times of Globalisation. Antipode, 33(3), 531-549.

Gammelsaeter, H. (2010). Institutional Pluralism and Governance in "Commercialized" Sports Clubs. European Sport Management Quarterly, 10(5), 569-594.

Goldsmith, A. (2002). Business Associations and Better Governance in Africa. Public Administration and Development, 22, 39-49.

Greenwood, R., Raynard, M., Kodeih, F., Micelotta, E., \& Lounsbury, M. (2011). Institutional Complexity and Organizational Responses. Academy of Management Annals, 5(1), 317-371.

Hartono, A. (2011). State-Business Relations in Post-1998 Indonesia: The Role of Kadin. Doctoral Thesis. Groningen: University of Gronignen.

Hatton Bank. (2015). HNB Awarded the Top 10 Best Corporate Citizens Award by the Ceylon Chamber of Commerce . Retrieved from Hatton National Bank Media Centre: https://www.hnb.net/media-center/2015/hnb- 
awarded-the-top-10-best-corporate-citizens-award-by-the-ceylonchamber-of-commerce

Hicks, J. (2004, April). The Politics of Wealth Distribution in Post-Soeharto Indonesia: Political Power, Corruption and Institutional Change. $P h D$ Dissertation. Leeds: University of Leeds.

Hicks, J. (2012, November 15). A False Start? Indonesian Business Associations as Democratic Actors in the Immediate Post-Soeharto Era. Inonesian Studies Working Papers No 15. (T. Dibley, \& K. Foulcher, Eds.) Sydney, New South Wales, Australia: Department of Indonesian Studies, Sydney University.

Jayawickrama, S. (2004). The Ceylon Chamber of Commerce 1839 - 2004: A Historical Review. Colombo: Ceylon Chamber of Commerce.

Kowal, M. (2018). Corporate politicking, together: trade association ties, lobbying, and campaign giving. Business and Politics, 20(1), 98-131.

Kraatz, M., \& Block, E. (2008). Organizational Implications of Institutional Pluralism. In R. Greenwood, C. Oliver, K. Sahlin, \& R. Suddaby (Eds.), The Handbook of Organizational Institutionalism (pp. 243-275). Thousand Oaks: Sage.

Lawrence, T., \& Suddaby, R. (2006). Institutions and institutional work. In S. Clegg, C. Hardy, T. Lawrence, \& W. Nord (Eds.), Handbook of Organizational Studies (pp. 214-254). London: Sage.

Lounsbury, M. (2007). A Tale of Two Cities: Competing Logics and Practice Variation in the Professionalizing of Mutual Funds. The Academy of Management Journal, 50(2), 289-307.

Lucas, J. (1997). The Politics of Business Associations in the Developing World. Journal of Developing Areas, 32(1), 71-96.

Moore, M., \& Hamalai, L. (1993). Economic Liberalization, Political Pluralism and Business Associations in Developing Countries. World Development, 21(12), 1895-1912.

Mortimer, D., Bain, L., \& Bond, S. (2004). Employer Association Strategy in a Decentralised Employment Relations System: The Case of the Retail Industry. Employment Relations Record, 4(2), 33-45. 
Nguyen, T. (2014a). Business associations and the politics of contained participation in Vietnam. Australian Journal of Political Science, 49(2), 334-349.

Nguyen, T. (2014b). Rethinking State-Society Relations in Vietnam: The Case of Business Associations in Ho Chi Minh City. Asian Studies Review, 38(1), 87-106.

Olson, M. (1965). The Logic of Collective Action: Public Goods and the Theory of Goods. Cambridge: Harvard University Press.

Olson, M. (1982). The Rise and Decline of Nations. New Haven: Yale University Press.

Önis, Z., \& Türem, U. (2001). Business Globalization and Democracy: A Comparative Analysis of Turkish Business Associations. Turkish Studies, 2(2), 94-120.

Perry, M. (2008). Exploring the Logics of Trade Association Membership. 25th Celebration Conference 2008 on Entrepreneurship and Innovation Organizations, Institutions, Systems and Regions. Copenhagen: DRUID.

Pratt, M., \& Foreman, P. (2000). Classifying Managerial Responses to Multiple Organizational Identities. The Academy of Management Review, 25(1), 1842.

Reay, T., \& Hinings, C. (2009). Managing the Rivalry of Competing Institutional Logics. Organization Studies, 30(6), 629-652.

Richards, D. (1996). Elite Interviewing: Approaches and Pitfalls. Politics, 16(3), 199-204.

Schmitter, P., \& Streeck, P. (1999, March). The Organization of Business Interest: Studying the Associative Action of Business in Advanced Industrial Societies. MPIfG Discussion Paper 99/1. Cologne, Germany: Max Planck Institut für Gesellschaftsforschung.

Sheldon, P., \& Thornthwaite, L. (2004). Business or Association? The Strategic Response of Employer Associations to the Decentralisation of Bargaining in Australia. Economic and Labour Relations Review, 15(1), 128-158.

Sheldon, P., Nacamulli, R., Paoletti, F., \& Morgan, D. (2014). Employer Association Responses to the Effects of Bargaining Decentralization in 
Australia and Italy: Seeking Explanations from Organizational Theory. British Journal of Industrial Relations, 1-32.

Sheldon, P., Paoletti, F., \& Nacamulli, R. (2009). Clients or Members? Organisational Strategies of Employer Associations in Australia and Italy in Response to Industrial Relations Decentralisation. Refereed Proceedings of the 15th World Congress of the International Industrial Relations Association. Sydney: International Industrial Relations Association.

Sirait, G. (2014). Employment Relations in Indonesia's Retail Sector: Institutions, Power Relations and Outcomes. PhD Thesis. Sydney: University of Sydney.

Spooner, K. (2004). The Printing Industries Association of Australia: A Survey of Members' Challenges and Needs. International Journal of Employment Studies, 12(2), 53-72.

Streeck, W., \& Schmitter, P. (1985). Private Interest Government: Beyond Market and State. London: Sage.

Thornthwaite, L., \& Sheldon, P. (2012). Employer and Employer Association Experiences of Enterprise Bargaining: Being Careful What You Wish For. Labour and Industry, 22(3), 255-274.

Thurbon, E. (2016). Trade agreements and the myth of policy constraint in Australia. Australian Journal of Political Science, 51(4), 636-651.

Trochim, W. (2006). Qualitative Approaches. Retrieved from Research Methods Knowledge Base: http://www.socialresearchmethods.net/kb/qualapp.php

Unger, B., \& van Waarden, F. (1999). Interest Associations and Economic Growth: A Critique of Mancur Olson's "Rise and Decline of Nations". Review of International Political Economy, 6(4), 425-467.

Welch, C., Marschan-Piekkari, R., Penttinen, H., \& Tahvanainen, M. (2002). Corporate Elites as Informants in Qualitative International Business Research. International Business Research Review, 11, 611-628.

Wood, G., Deeg, R., \& Wilkinson, A. (2014). The Rise and Fall of Complementarity and National Institutional Orders. The Journal of Comparative Economic Studies, 9, 29-46. 
You, K. (2016). Employer Association Renewal and Adaptation: The Experience of the National Retail Association. International Journal of Employment Studies, 24(1), 62-77.

You, K., \& Barry, M. (2016). Intra-industry competition among employer associations: a case study of the retail sector. Labour \& Industry, 26(2), 120-137.

$\mathrm{Yu}$, K. (2013). Institutionalization in the Context of Institutional Pluralism: Politics as a Generative Process. Organization Studies, 34(1), 105-131.

Yu, K. (2015). Institutional Pluralism, Organizations, and Actors: A Review. Sociology Compass, 9(6), 464-476. 